\title{
PODXL wt Allele
}

National Cancer Institute

\section{Source}

National Cancer Institute. PODXL wt Allele. NCI Thesaurus. Code C106449.

Human PODXL wild-type allele is located within 7q32-q33 and is approximately $58 \mathrm{~kb}$ in length. This allele, which encodes podocalyxin protein, is involved in both cell-cell adhesion and cell migration. Aberrant expression of the gene in tumors is associated with a poor prognosis. 